\title{
化学工場爆発事故後に採取した松花江の魚試料中の ニトロベンゼンの定量
}

田中恵理子 ${ }^{1}$, 代 英 杰 $^{1}$, 林 永 波 $^{2}$, 古月 文志 ${ }^{1}$, 田中 俊逸 ${ }^{\circledR 1}$, 神 和 夫 $^{3}$, 平間 祐志 $^{3}$

2005 年 11 月中国吉林市にある吉林石油化学会社の工場で起こった爆発事故によって, ニトロベンゼンが 中国東北部を流れる松花江に流入し，河川を污染した．本研究では，污染物質が通過したハルビン市内の松 花江で採取された魚試料中のニトロベンゼンの測定を行った。 また，ニトロベンゼンの代謝によって生成す ると予想されるニトロフェノール類の定量を行った。 ニトロベンゼンの抽出と濃縮には, 精油定量装置を用 い，魚試料の調製，魚試料の前処理，抽出条件等について検討した，その結果，2006 年 3 月と 10 月に採取 した魚試料からは比較的高い濃度のニトロベンゼンが検出された．また，魚試料からニトロベンゼンの代謝 物と思われる $o-, m-, p$ ニトロフェノールが検出された.

\section{1 緒言}

2005 年 11 月 13 日, 中国の吉林省吉林市にある吉林石油 化学会社の工場で爆発事故が発生した。この化学工場は中 国国内でも最大級のアニリン製造工場であったため, ベン ゼン, ニトロベンゼン, アニリンの混合物計約 100 トンが 中国東北部を流れる松花江（Fig. 1）に流出した ${ }^{12)}$. 污染 带は 11 月 25 日には下流のハルビン市に到達し, 通過時の ニトロベンゼン濃度は $0.58 \mathrm{mg} / \mathrm{L}$ と飲料水における中国の 基準值 $(0.017 \mathrm{mg} / \mathrm{L})$ の約 33 倍もの值であった ${ }^{3)}$. 污染帯 は中国黒龍江省同江市（ロシア国境と接する都市）を通過 してアムール川に入り，12月 22 日には，ロシア国境の八 バロフスク市へ到達した，その後污染物質はオホーツク海 に流出したものと思われる.UNEP（国連環境計画）の発 表によると, 污染物質のうちベンゼンはその揮発性によっ てすぐに減少し，また，アニリンの濃度は低かったことか ら，污染带の主なものはニトロベンゼンであると言われて いる ${ }^{4)}$.

著者らは, 流出事故後の 2006 年 3 月と 10 月, 2007 年 10 月にハルビン市及び吉林市を訪問し, 事故後の松花江の 水や河川堆積物, ならびに魚試料を採取し, これらの試料 中のニトロベンゼン濃度の測定を行った，その結果, 採取 時に扔ける河川水中のニトロベンゼン濃度は非常に低いも

\footnotetext{
${ }^{1}$ 北海道大学大学院地球環境科学研究院環境起学専攻 : 060-0810 北海道札幌市北区北 10 条西 5 丁目

2 中国東北林業大学林学院 : 150040 中国ハルビン市香坊区和興 路 26 号

3 北海道立衛生研究所：060-0819 北海道札幌市北区北 19 条西 12 丁目
}

のであることが判明している ${ }^{5 / 6)}$ ．しかし，松花江に生息し ている魚介類中のニトロベンゼン濃度に関する報告はほと んど行われていない，そこで，本論文では，松花江で採取 された魚試料中のニトロベンゼンの測定結果について報告 する．魚試料中のニトロベンゼンの定量においては，試料 からのニトロベンゼンを抽出するために精油定量装置を用 い，また，共雑物との分離のために，フロリジルカラムと 硝酸銀シリカゲルカラムを用い，それぞれの濃縮，分離条 件に関する検討を行った，検討した方法により爆発事故後 の松花江で採取された魚試料について測定を行った．更 に，ニトロベンゼンの代謝によって生成すると予想される ニトロフェノール類の分析も行った.

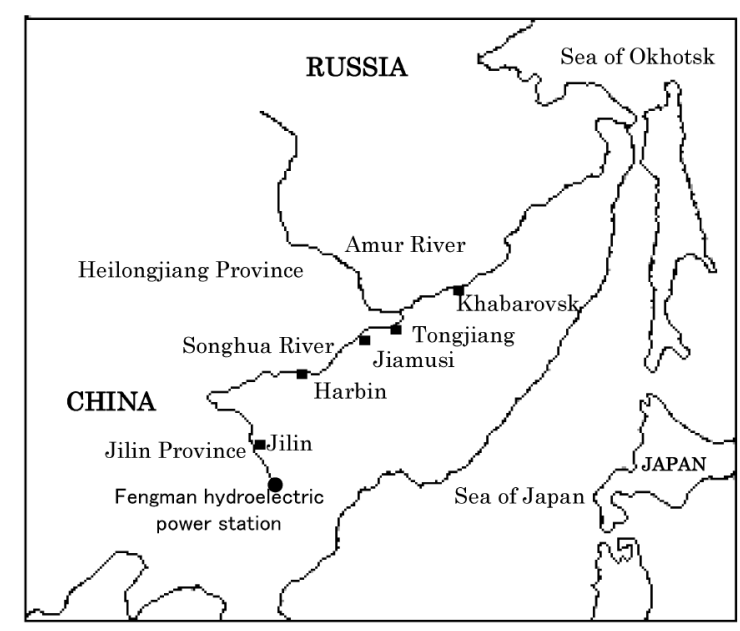

Fig. 1 Map of the Songhua River 


\section{2 実験}

\section{$2 \cdot 1$ 試 薬}

魚試料からのニトロベンゼンの抽出溶媒として, ヘキサ ン 5000 (残留農薬・PCB 試験用, 和光純薬製) を用いた. ニトロベンゼンのサロゲートとして, ニトロベンゼン- $d_{5}$ (環境分析用，和光純薬製）をへキサンで希釈して，500 $\mathrm{ng} / \mathrm{mL}$ としたものを用いた. 炭酸ナトリウム, 塩化ナトリ ウム, 無水硫酸ナトリウムはそれぞれ市販の試薬（和光純 薬製）の適当量を電気炉にて $350^{\circ} \mathrm{C}, 650^{\circ} \mathrm{C}, 450^{\circ} \mathrm{C} て ゙ 24$ 時間焼成したものを用いた。 ニトロベンゼン, ジクロロメ タン (HPLC 用), 炭酸ナトリウム ( $\mathrm{pH}$ 測定用), メタノ ール (HPLC用), フロリジール PR, $o-, \quad m-, \quad p$-ニトロフ エノール，4-ニトロフェノール- $d_{4}$ 体はすべて和光純薬製の 試薬を用いた。 その他の試薬についてもすべて市販の特級 試薬，又はそれに準ずるものを使用した。

\section{$\mathbf{2} \cdot \mathbf{2}$ 装 置}

ニトロベンゼンの抽出と濃縮には市販の精油定量装置 (丸底フラスコ $1 \mathrm{~L}$, 受器 $4 \mathrm{~mL}$ 共通すり合わせ球管, 冷却 器 $180 \mathrm{~mm}$ : 柴田科学製) を用いた. $10 \%$ 硝酸銀シリカゲ

Table 1 GC/MS conditions for quantitative nitrobenzene determination

\begin{tabular}{ll}
\hline $\begin{array}{l}\text { Chromatograph } \\
\text { Column }\end{array}$ & $\begin{array}{l}\mathrm{ZB}-1(30 \mathrm{~m} \times 0.25 \mathrm{~mm} \text { i.d., } 1 \mu \mathrm{m} \\
\text { film })\end{array}$ \\
Carrier gas & $\mathrm{He}(1.7 \mathrm{~mL} / \mathrm{min})$ \\
Injector volume & $2 \mu \mathrm{L}$ \\
Split ratio & $52 \mathrm{~cm} / \mathrm{s}$ \\
Injector temperature & $200^{\circ} \mathrm{C}$ \\
Detector temperature & $280^{\circ} \mathrm{C}$ \\
Oven temperature program & $60^{\circ} \mathrm{C}(2 \mathrm{~min})-10^{\circ} \mathrm{C} / \mathrm{min}-140^{\circ} \mathrm{C}-$ \\
& $20^{\circ} \mathrm{C} / \mathrm{min}-240^{\circ} \mathrm{C}$ \\
& \\
Mass spectormeter & $280^{\circ} \mathrm{C}$ \\
Interface temperature & $1.3 \mathrm{kV}$ \\
Electron multiplier voltage & $\mathrm{SIM}$ \\
Scan mode &
\end{tabular}

ルは未洗浄のワコーゲル C-200に $1 \mathrm{~g}$ 当たり $40 \%$ 硝酸銀溶

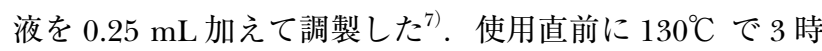
間活性化しデシケーター中で放冷したものを使用した．硝 酸銀シリカゲルカラムは少量の石英ウールを詰めたパスツ ールピペットに，無水硫酸ナトリウム $5 \mathrm{~mm}, 10 \%$ 硝酸銀 シリカゲル $35 \mathrm{~mm}$, 無水硫酸ナトリウム $5 \mathrm{~mm}$ の順に積層 して調製した．魚試料のホモジナイズのために，フードプ ロセッサー：(National MK-K580）を用いた。 フロリジル カラムの溶出試験にはカラムクロマトグラフ管を用い, 石 英ウール（B グレード $5 \sim 12 \mu \mathrm{m} ： \mathrm{GL}$ サイエンス製）上に フロリジール樹脂を充填した. 魚試料中のニトロベンゼン とニトロフェノール類の濃度を求めるため, 四重極型ガス クロマトグラフィー/質量分析 (GC/MS) システム QP5050A （Shimadzu Co., Japan）を用い, ニトロベンゼンとニトロ フェノール類の分析条件をそれぞれ Table 1 と Table 2 に 示した.

\section{$2 \cdot 3$ 魚試料の調製}

松花江の魚試料は，その一部を松花江で漁をしている漁 師から，また一部は釣人から提供を受けた。魚種や魚のサ イズ等均一なものの入手は困難であったが，入手したもの

Table 2 GC/MS conditions for quantitative nitrophenol determination

\begin{tabular}{ll}
\hline $\begin{array}{l}\text { Chromatograph } \\
\text { Column }\end{array}$ & $\begin{array}{c}\mathrm{ZB}-1(30 \mathrm{~m} \times 0.25 \mathrm{~mm} \text { i.d., } 1 \mu \mathrm{m} \\
\text { film })\end{array}$ \\
Carrier gas & $\mathrm{He}(1.7 \mathrm{~mL} / \mathrm{min})$ \\
Injector volume & $2 \mu \mathrm{L}$ \\
Split ratio & $52 \mathrm{~cm} / \mathrm{s}$ \\
Injector temperature & $230^{\circ} \mathrm{C}$ \\
Detector temperature & $250^{\circ} \mathrm{C}$ \\
Oven temperature program & $50^{\circ} \mathrm{C}(2 \mathrm{~min})-20^{\circ} \mathrm{C} / \mathrm{min}-150^{\circ} \mathrm{C}-$ \\
& $77^{\circ} \mathrm{C} / \mathrm{min}-190^{\circ} \mathrm{C}\left(20^{\circ} \mathrm{C} / \mathrm{min}\right)-$ \\
& $280^{\circ} \mathrm{C}$ \\
Mass spectormeter & \\
Interface temperature & $280^{\circ} \mathrm{C}$ \\
Electron multiplier voltage & $1.3 \mathrm{kV}$ \\
Scan mode & $\mathrm{SIM}$ \\
\hline
\end{tabular}

Table 3 Fish samples collected in Songhua River at Harbin city

\begin{tabular}{ccccc}
\hline Fish samples & Collecting date & Species & Size/cm & $\begin{array}{c}\text { Nitrobenzene } \\
\text { quantity/ng g }\end{array}$ \\
\hline A & March-06 & Yellow catfish & 25 & 30.2 \\
B & March-06 & Yellow catfish & 14 & 19.7 \\
C & October-06 & Carp & 30 & 13.6 \\
D & October-06 & Longnose gudgeon & 12 & 15.8 \\
E & October-06 & White fish & 10 & 9.86 \\
F & October-07 & Crucian carp & 15 & 2.73 \\
G & October-07 & Yellow catfish & 13 & 3.31 \\
H & October-07 & Perch & 14 & 1.14 \\
\hline
\end{tabular}




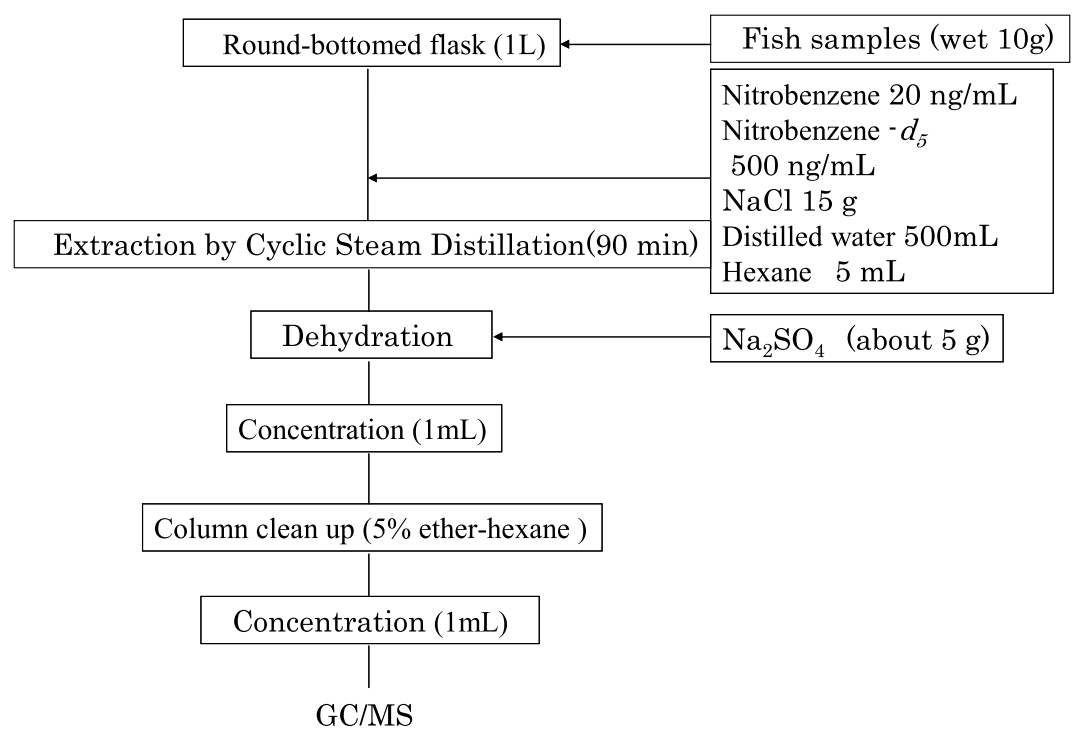

Fig. 2 Flow chart for analytical procedure for nitrobenzene in fish samples

すべての測定を行った（Table 3 に入手した魚種とサイズ 等を示す). 魚試料はフードプロセッサーでホモジナイズ し, $10 \mathrm{~g}$ ずつに小分けして, 冷凍庫 $\left(-18^{\circ} \mathrm{C}\right)$ で冷凍保存 した.この魚試料の調製法は文献に従( ${ }^{899)}$, Fig. 2 に示す 操作によって行った．ホモジナイズした魚試料 $10 \mathrm{~g}$ （添加 実験では $20 \mathrm{ng} / \mathrm{mL}$ のニトロベンゼン溶液を $1 \mathrm{~mL}$ 添加し た）を $1 \mathrm{~L}$ 丸底フラスコに取り，塩化ナトリウム $15 \mathrm{~g}$ 及び サロゲート溶液 $\left(500 \mathrm{ng} / \mathrm{mL}\right.$ ニトロベンゼン- $\left.d_{5}\right)$ を $1 \mathrm{~mL}$ 添加し, よく混合後, 精製水 $500 \mathrm{~mL}$, ヘキサン $5 \mathrm{~mL}$ 及び 沸石を加えた. 精油定量装置の受器にはあらかじめ精製水 $4 \mathrm{~mL}$ とへキサン $3 \mathrm{~mL}$ を入れ, 丸底フラスコを緩やかに加 熱し, ヘキサンが留出し始めてから, 更に 90 分間加熱し た. 放冷後, 受器の水相を捨て, ヘキサン相を分取した. 更に受器を少量のへキサンで洗浄し，これを分取したへキ サン相と合わせて無水硫酸ナトリウムで脱水後, ナス型フ ラスコに移し, エバポレーター $\left(30^{\circ} \mathrm{C}, 180 \mathrm{~Pa}\right)$ で $1 \mathrm{~mL}$ で濃縮した。この濃縮液をあらかじめ調製しておいたフロ リジルカラムに負荷した，ナス型フラスコの内部を洗った ものを含むへキサン $30 \mathrm{~mL}$ でカラムを洗浄した後， $5 \%$ ジ エチルエーテルーヘキサン $45 \mathrm{~mL}$ で溶出させた.

最初の溶出液 $10 \mathrm{~mL}$ を捨て, 残りの $35 \mathrm{~mL}$ を溶出液と して分取した，得られた溶出液を再びナスフラスコに移 し, エバポレーターで $1 \mathrm{~mL}$ に濃縮した後, $4 \mathrm{~mL}$ のヘキサ ンで洗浄した硝酸銀シリカゲルカラムに負荷し, ヘキサン $8 \mathrm{~mL}$ で溶出させた．負荷直後の溶出液とへキサンを分取 し, 窒素で $1 \mathrm{~mL}$ に濃縮した後, GC/MS で定量した. 測定 は 1 試料につき 3 回行った.

\section{$2 \cdot 4$ 代謝物測定のための魚試料の前処理}

代謝物測定のための前処理法の概要を Fig. 3 に示す. ホ
モジナイズした魚試料 $10 \mathrm{~g}$ を $50 \mathrm{~mL}$ の共栓付き遠沈管に 正確に採取し，サロゲート溶液 $1 \mathrm{~mL}(500 \mathrm{ng} / \mathrm{mL}$ の 4 -二 トロフェノール- $\left.d_{4}\right)$ とメタノール $25 \mathrm{~mL}$ を加えて 10 分間 振とう抽出する. 遠心分離操作 (3000 rpm, 10 分間) によ り, 上澄み液のメタノール相を分離した後, 残查にアセ卜 ン $25 \mathrm{~mL}$ を加えて振とう抽出し, 引き続き遠心分離操作を 行った．更に残查にメタノール $25 \mathrm{~mL}$ を加えて振とう抽 出・遠心分離を行った，得られた抽出液を $200 \mathrm{~mL}$ の分液 漏斗に移し，ヘキサン $18 \mathrm{~mL}$ を添加してへキサンを飽和さ せ, 10 分間振とうした後, 十分静置して, 下相のメタノー ル相を採取し, 最初のメタノール相に合わせる。得られた 抽出液は, ジクロロメタン $50 \mathrm{~mL}$ に溶解した後, $500 \mathrm{~mL}$ の分液漏斗に移し， $5 \%$ 炭酸ナトリウム水溶液 $250 \mathrm{~mL}$ を 加えて, 10 分間振とうして逆相抽出を行った後, 十分に静 置して分液し, ジクロロメタン相を捨てる. 水相に再度ジ クロロメタン $25 \mathrm{~mL}$ を加え同様の操作で洗浄し, ジクロロ メタン相を捨てる. この洗浄操作を再度繰り返した後, 水 相に濃塩酸 $(4.7 \mathrm{~mL})$ を添加し, 緩やかに振とうして発生 する二酸化炭素ガスを除去しながら $\mathrm{pH} 3.5$ 以下にする. 水 相にジクロロメタン $50 \mathrm{~mL}$ を加えて 10 分間振とう後, 静 置してジクロロメタン相を採取し, 水相は再度ジクロロメ タン $25 \mathrm{~mL}$ を加えて, 同様な抽出操作を繰り返す. 得られ たジクロロメタン抽出液を $200 \mathrm{~mL}$ のビーカーに入れ, 無 水硫酸ナトリウムを用いて脱水した後, $100 \mathrm{~mL}$ のナス型 フラスコに移し, エバポレーターで約 $5 \mathrm{~mL}$ まで減圧濃縮 する。濃縮液は $15 \mathrm{~mL}$ のジクロロメタンを用いて $100 \mathrm{~mL}$ の分液漏斗に移した後， $5 \%$ 塩化ナトリウムを含む $0.5 \%$ 炭酸ナトリウム水溶液 $25 \mathrm{~mL}$ を加えて, 10 分間振とうし, 目的物質を逆抽出し，ジクロロメタン相は捨てる。 $0.5 \%$ 炭酸ナトリウム水溶液相は, ジクロロメタン $10 \mathrm{~mL}$ を加え 


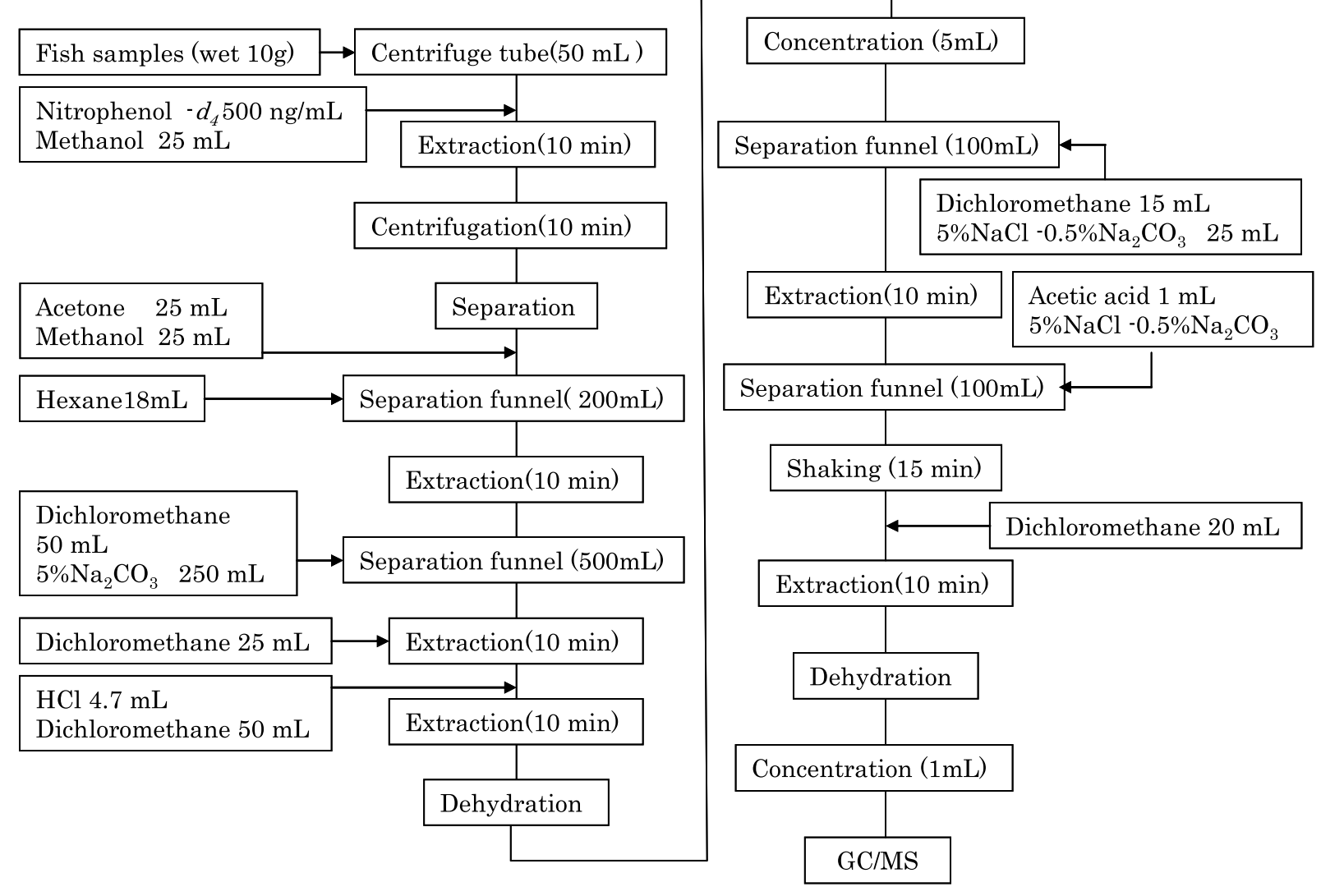

Fig. 3 Flow chart for pretreatment of nitrophenol in fish samples

て再度洗浄した後, 共栓付きメスシリンダーに移し, $30 \mathrm{~mL}$ にする. 5\% 塩化ナトリウムを含む $0.5 \%$ 炭酸ナト リウム水溶液を用いて, $100 \mathrm{~mL}$ 分液漏斗に移し, アセチ ル化のための前処理液とする.

アセチル化用前処理液に $1 \mathrm{~mL}$ の無水酢酸を加え, 緩や かに振とうして, 発生する二酸化炭素ガスを除去した後, 直ちに 15 分間振とうすることでアセチル化を行った. 反 応液にジクロロメタン $20 \mathrm{~mL}$ を加えて, 10 分間振とう抽 出し, 静置後, ジクロロメタン相を採取する. 水相は, 再 度ジクロロメタン $10 \mathrm{~mL}$ を加えて, 同様な抽出操作を繰り 返す。得られたジクロロメタン抽出液を $100 \mathrm{~mL}$ のビーカ 一に入れ，ヘキサンを $10 \mathrm{~mL}$ 加えて無水硫酸ナトリウムで 脱水する. 抽出液はへキサンを用いて $100 \mathrm{~mL}$ のナス型フ ラスコに移し，エバポレーターを用いて減圧濃縮する，濃 縮液はへキサンを用いて試験管に移し, 窒素ガスを吹き付 けて $1 \mathrm{~mL}$ まで濃縮した後, GC/MS で定量した.

\section{3 結果と考察}

\section{$3 \cdot 1$ 精油定量装置における抽出条件}

最初に精油定量装置にする抽出操作を行う際の抽出時間 と再現性の検討を行った. $1 \mathrm{~L}$ の丸底フラスコに塩化ナト リウム $15 \mathrm{~g}$, ニトロベンゼン $500 \mathrm{ng} / \mathrm{mL}$ を $1 \mathrm{~mL}$, 精製水 $500 \mathrm{~mL}$, ヘキサン $5 \mathrm{~mL}$ 及び沸石を加え, 精油定量装置の
受器に精製水 $4 \mathrm{~mL}$ とヘキサン $3 \mathrm{~mL}$ を加えて冷却器をセ ットし，マントルヒーターで緩やかに加熱した。ヘキサン が留出し始めたら，更に 90 分間（抽出時間検討の場合は $60,90,120,150$ 分間) 加熱した. 冷却後, 精油定量装置 の受器内の水相を捨て, ヘキサン相を分取した。更に受器 内を少量のへキサンで洗浄し，これを分取したへキサン相 と合わせて無水硫酸ナトリウムで脱水し, サロゲート溶液 $\left(500 \mathrm{ng} / \mathrm{mL}\right.$ のニトロベンゼン $\left.-d_{5}\right)$ を $1 \mathrm{~mL}$ 加えた。 その 後, エバポレーター $\left(30^{\circ} \mathrm{C}, 180 \mathrm{~Pa}\right)$ で $1 \mathrm{~mL}$ に濃縮した 後, GC/MS で定量した. 抽出時間を変化させた時の結果 を Fig. 4 に示す. 90，120，150 分では $90 \%$ 以上の回収率 が得られた。一般に精油定量装置を用いた抽出では，一部 の半揮発性物質以外は $90 \sim 120$ 分の抽出時間が最も効率 が良く, その後は回収率の大きな変化はなく, 一定の回収 率が得られるという報告と一致した ${ }^{10)}$.この条件で抽出率 の再現性は相対標準偏差（RSD）は $3 \%$ 程度であり，これ らのことから本研究では, 抽出時間を 90 分とした. また, 精油定量装置を用いた本操作方法によってニトロベンゼン を安定に，高効率に回収できることを確認した。

\section{$3 \cdot 2$ フロリジルカラムの溶出試験}

次に, 一連の抽出操作の最後に行うクリーンアップに用 いるフロリジルカラムの溶出に関する検討を行った. フロ 


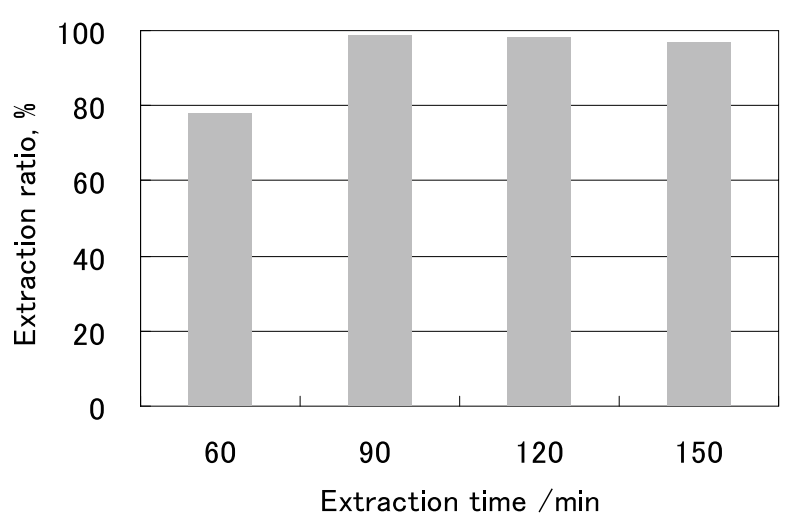

Fig. 4 Recovery of nitrobenzene from $500 \mathrm{~mL}$ water containing nitrobenzene after different distillation times (Concentration of nitrobenzene : $500 / \mathrm{ng} \mathrm{mL}^{-1}$ )

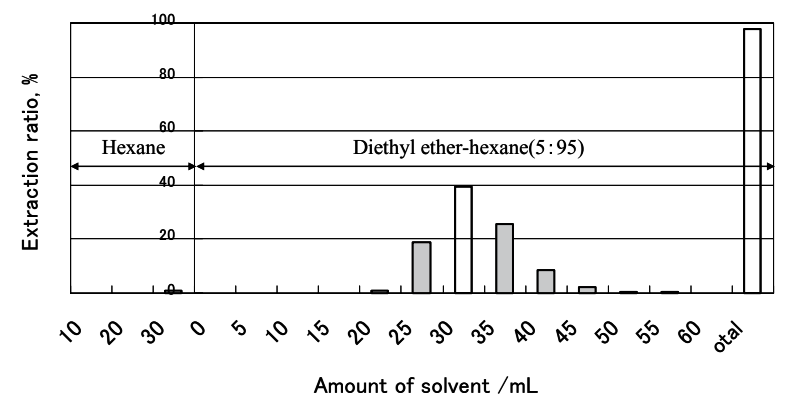

Fig. 5 Elusion patterns of nitrobenzene from the Florisil column Eluent : diethyl ether-hexane (5:95)

リジルカラムに, ニトロベンゼン $500 \mathrm{ng} / \mathrm{mL}$ を $1 \mathrm{~mL}$ 負荷 し, 溶出液としてへキサン $30 \mathrm{~mL}$ と $5 \%$ ジエチルエーテ ルーヘキサン $60 \mathrm{~mL}$ を用いてニトロベンゼンの溶出挙動に ついて検討した．流下するへキサンは $10 \mathrm{~mL}$ ずつ， $5 \%$ ジ エチルエーテルーヘキサンは $5 \mathrm{~mL}$ ずつ試験管に分取し, そ れぞれにサロゲート溶液（ニトロベンゼン-d $500 \mathrm{ng} /$ $\mathrm{mL}$ )を $1 \mathrm{~mL}$ ずつ加えエバポレーターで約 $1 \mathrm{~mL}$ に濃縮し た. それぞれのフラクションに含まれるニトロベンゼン量 は GC/MS を用いて測定した. フロリジルカラムによるニ トロベンゼンの溶出と溶離液量の関係を Fig. 5 に示した. ニトロベンゼンはへキサンでは溶出せず， $5 \%$ ジエチルエ ーテルーヘキサンでは 15〜 $55 \mathrm{~mL}$ の範囲で $95 \%$ が溶出さ れ, このうち $20 \sim 35 \mathrm{~mL}$ の範囲で最も溶出量が多く, 45 〜 $55 \mathrm{~mL}$ の範囲ではわずかしか溶出されないことを確認 した.このため, $5 \%$ ジエチルエーテルーヘキサンによる溶 出液は, $10 〜 45 \mathrm{~mL}$ を分取することとした.

\section{$3 \cdot 3$ 松花江で採取した魚試料中のニトロベンゼン濃度}

一連の分析操作を用いて, 魚試料に $20 \mathrm{ng} / \mathrm{mL}$ のニトロ ベンゼン溶液 $1 \mathrm{~mL}$ を添加した時の添加回収実験の結果と

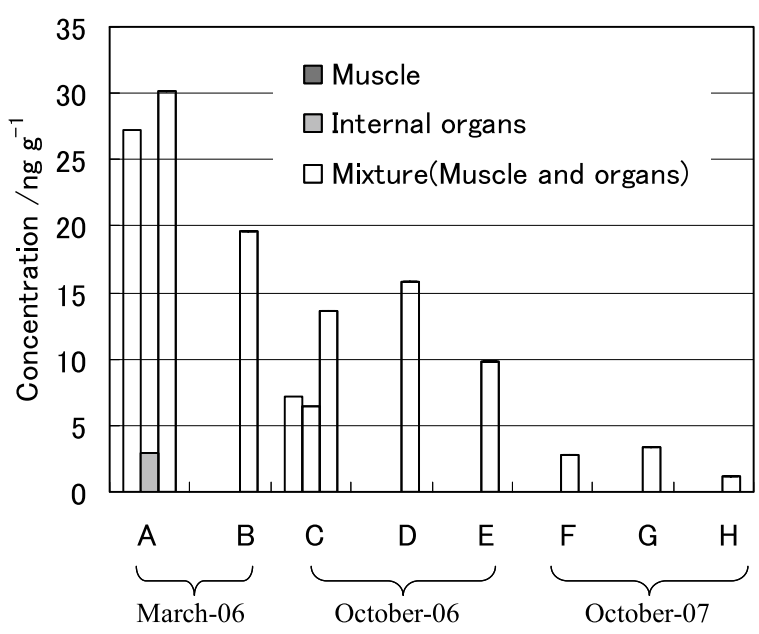

Fig. 6 Concentration of nitrobenzene in fish samples

して, 平均回収率は $107 \%$ であり, 相対標準偏差は $5 \%$ と 良好な結果であり, また, 検出限界は $0.75 \mathrm{ng} / \mathrm{g}$ であった.

松花江で採取した魚試料中のニトロベンゼンを測定した 結果を Fig. 6 と Table 3 に示す. 2006 年 3 月に採取した魚 試料 $\mathrm{A} ， \mathrm{~B}$ と 10 月に採取した $\mathrm{C} ， \mathrm{D}, \mathrm{E}$ からは比較的高い 濃度のニトロベンゼンが検出された。 しかし， 2007 年 10 月に採取した魚試料 $\mathrm{F}, \mathrm{G}, \mathrm{H}$ 中のニトロベンゼン濃度は かなり低いものであった.

\section{$3 \cdot 4$ 生体内代謝物の分析}

ニトロベンゼンは高蓄積性ではなく ${ }^{11)}$, 一旦体内に入っ ても体外へ排出されることが知られている ${ }^{12) ~ 14)}$. また一 方, ニトロベンゼンは魚の体内に入ると, 二つの主要代謝 経路によって代謝されてゆく，一つはアニリンに還元さ れ，水酸化によりアミノフェノールになる系と，もう一つ はニトロベンゼンが直接水酸化され，ニトロフェノールを 形成し，その後にアミノフェノールとなる系である ${ }^{15)}$. 魚 の体内に入ったニトロベンゼンの変化を知るためには，こ れらの代謝物質を測定することが必要であると考えた．今 回は，ニトロフェノールを測定することとしたが，二トロ フェノールは生体内でグルクロン酸や硫酸抱合体になって いて，そのままでは定量が困難である，そこで，抱合体を 分解した後に誘導体化を行って測定することとした．誘導 体化の方法としては, ペンタフルオロベンジル（PFB）化, シリル化, アルキル化法などがあるが, 試料を炭酸ナトリ ウム水溶液などの塩基存在下において, 無水酢酸で直接ア セチル化する方法が一般的である．この方法による誘導体 化の利点は, (1) 回収率が高く, (2) GC 分析において構造異 性体の分離やピーク形状が良い, (3) 誘導体が安定などで ある.このため, 今回は直接アセチル化を行い, 誘導化に より生成した物質を GC/MS で測定した ${ }^{16) 17)}$. 松花江の魚 試料 A, C, H について測定結果を Fig. 7 に示す. A, C, 


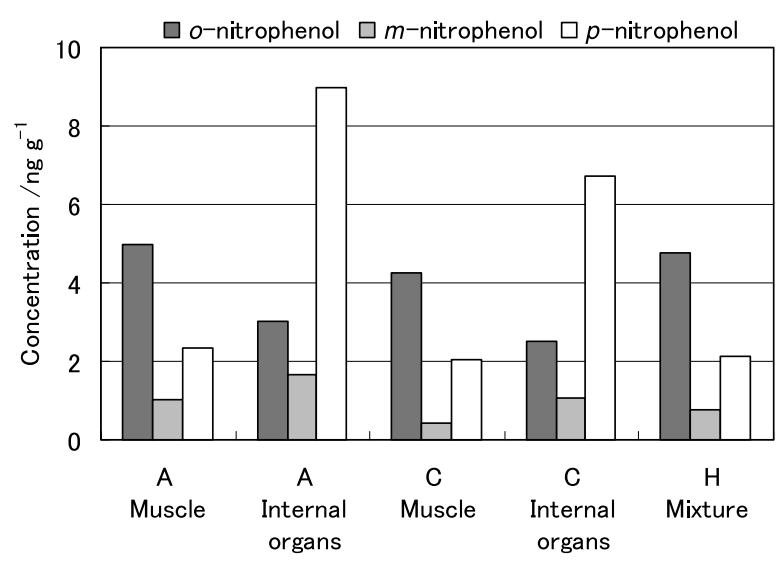

Fig. 7 Concentration of nitrophenol in fish samples from Songhua river (Fish $\mathrm{H}$ is mixture of muscle and internal organs)

$\mathrm{H}$ からはいずれも $o-, \quad m-, \quad p$-トロフェノールが検出され た。 また, 異性体の存在割合は身の部分と内蔵部で若干異 なっていた。 ニトロフェノールが魚試料中に存在している ということは，ニトロベンゼンが体内で代謝されたとも考 えられるが，ニトロフェノール自体を摂取したとも考えら れ，ニトロベンゼンの污染のみの結果であるとは一概には 言えない. しかし，魚試料中にニトロベンゼンとニトロフ エノールが検出されたことから，ニトロベンゼンによる魚 試料の污染とその代謝の可能性が見いだせた.

$$
4 \text { 結 言 }
$$

中国の松花江で採取された魚試料中のニトロベンゼンの 濃度を分析した結果, すべての魚試料からニトロベンゼン が検出された. 1991 年の環境庁の調查によれば, 日本にお ける環境水中に生息する魚類において検查した 147 の個体 のうち 8 個体からニトロベンゼンが検出され，検出範囲は nd（不検出）から $26 \mathrm{ng} / \mathrm{g}$ （95 パーセンタイルとして 4.4 $\mathrm{ng} / \mathrm{g})$ とされている ${ }^{18)}$. 本研究で得られた松花江の魚飼料 のうち 2006 年 3 月に採取した魚体中のニトロベンゼンは, 日本で検出されたものの中の最大值に近い值を示してい る. 一方 2007 年に入手したものでは， かなり低い值とな っている. 入手した魚試料の数に限りがあり，また魚種や 魚のサイズが均一ではないが, 調査したすべての魚体中か らニトロベンゼンが検出されたことは, 事故によるニトロ
ベンゼンの流出の影響によるものと思われる，また，魚試 料中からはニトロフェノールも検出され, 体内に入ったニ トロベンゼンの代謝によって生成した可能性も示唆され た.

\section{文献}

1) L. Y. Zhu, B. L. Ma, L. Zhang: Chemosphere, 69, 1579 (2007).

2) Z. L. Li, M. Yang, D. Li, R. Qi, H. J. Liu, J. F. Sun, J. H. Qu : J. Environ. Sci., 20, 778 (2008).

3) 中国人民共和国国家基準, 地表水環境質基準，(中 国国家環境保護総局).

4) United Nations Environment Program (U.N.E.P.), The Songhua River Spill China, Field Mission Report. 2005.

5) 神 和夫, 平間祐志, 小林 智, 千葉真弘, 伊藤 八十男，林 永波，代 英杰，古月文志，田中俊 逸: 日本環境化学会第 16 回環境化学討論会講演要 旨集, p. 270 (2007).

6) 平間祐志, 神 和夫，林 永波，代 英杰，古月文 志, 田中俊逸 : 日本分析化学会北海道支部冬季研究 発表会講演要旨集, p. 58 (2007).

7) 日本薬学会編：“衛生試験法・注解”, p. 501 (2005), (金原出版).

8) 家合浩明, 田辺顕子, 川田邦明: 環境化学, 13, 993 (2003).

9) 日本国環境省総合環境政策局環境安全課編：“平成 13 年度化学物質分析法開発調査報告書”。

10) K. Kawata, A. Tanabe, H. Yagoh, T. Ibarak : J. AOAC internal., 86, 246 (2003).

11) 日本国環境省総合環境政策局環境安全課編：“二卜 ロベンゼン, 化学物質と環境”, (2002), (日本環境衛 生センター).

12) 財団法人化学物質評価研究機構 : 安全性点検 DATA (2002).

13) G. D., Veith, D. L., Defoe, B. V. Bergstedt : J. Fish. Res. Board can., 36, 1040 (1979).

14) D. Freitag, H. Geyer, A. Kraus, R. Viswanathan, D. Kotzias, A. Attar, W. Klein, F. Korte : Ecotox. Environ. Safety, 6, 60 (1982).

15) A. Almasi, E. Fischer, Pal Perjesi : J. Biochem. Biophys. Mwthods, 69, 43 (2006).

16) 倉田泰人：環境化学, 4, 55 (1994).

17) 倉田泰人: 埼玉県公害センター研究報, 19, 1 (1992)

18）新エネルギー・産業技術総合開発機構：“化学物質 の初期リスク評価書 Ver.1.0No.6 ニトロベンゼン暴 露評価”, (2005), (化学物質評価研究機構安全性評価 技術研究所). 


\title{
Determination of Nitrobenzene in Fish Samples Collected from the Songhua River after Explosion of Petrochemical Plant
}

\author{
Eriko TAnAKA ${ }^{1}$, Yingjie DAI ${ }^{1}$, Yongbo Lin $^{2}$, Bunshi Fugetsu ${ }^{1}$, \\ Shunitz TANAKA ${ }^{1}$, Kazuo Jin ${ }^{3}$ and Yuji Hirama ${ }^{3}$ \\ ${ }^{1}$ Graduate School of Environmental Earth Science, Hokkaido University, Nishi-5, Kita-10, Kita-ku, Sapporo-shi, \\ Hokkaido 060-0810 \\ ${ }^{2}$ School of Forestry, Northeast Forestry University, Harbin, China 150040 \\ ${ }^{3}$ Hokkaido Institute of Public Health, Nishi-12, Kita-19, Kita-ku, Sapporo-shi, Hokkaido 060-0819
}

(Received 11 November 2008, Accepted 28 May 2009)

By the accident of explosion at a petrochemical plant in Jilin city of China, on November, 13th, 2005, about 100 tons of nitrobenzene, benzene and aniline were spilled into the Songhua river flowing in the north-east area of China. Therefore, nitrobenzene in fish samples collected from the Songhua river in Harbin city after passing of contaminants were determined. A cyclic steam distillation apparatus for extraction and concentration of nitrobenzene in fish samples was used, and the preparation and pretreatment of a fish samples and extraction conditions were investigated. As a result, relatively high concentration of nitrobenzene was found out in fish samples collected in March and October of 2006. Nitrophenol, one of the expected products by metabolism of nitrobenzene in fish samples was also determined. $o-, m-, p$ - nitrophenol were detected in fish samples.

Keywords : Songhua river ; fish samples ; cyclic steam distillation ; nitrobenzene ; nitrophenol. 